\title{
Morphological deformities in the osseous structure in spotted sorubim Pseudoplatystoma coruscans (agassiz \& spix, 1829) with vitamin c deficiency
}

\author{
RODRIGO Y. FUJIMOTO ${ }^{1}$, RUDÃ F.B. SANTOS ${ }^{2}$ and DALTON J. CARNEIRO ${ }^{3}$ \\ ${ }^{1}$ Embrapa Tabuleiros Costeiros, Avenida Beira Mar, 3250, Bairro Jardins, 49025-040 Aracaju, SE, Brasil \\ ${ }^{2}$ Laboratório de Ictioparasitologia e Piscicultura, Universidade Federal do Pará, \\ Alameda Leandro Ribeiro, s/n, Bairro Aldeia, 68600-000 Bragança, PA, Brasil \\ ${ }^{3}$ Departamento de Zootecnia da Faculdade de Ciências Agrárias e Veterinárias, UNESP, \\ Campus de Jaboticabal, Prof. Paulo Donato Castellane, s/n, Bairro Zona Rural, 14884-900 Jaboticabal, SP, Brasil \\ Manuscript received on June 26, 2011; accepted for publication on April 24, 2012
}

\begin{abstract}
Vitamin $\mathrm{C}$ is essential for fish diets because many species cannot syntethize it. This vitamin is needed for bone and cartilage formation. Moreover, it acts as antioxidant and improve the immunological system. The present work investigated the effects of vitamin C diet supplementation to spotted sorubim (Pseudoplatystoma coruscans) fingerlings by frequency of bone and cartilage deformation. Ascorbyl poliphosphate (AP) was used as source of vitamin $\mathrm{C}$ in the diets for spotted sorubim fingerlings during three months. Six diets were formulated: one diet control (0 mg/kg of vitamin C) and 500, 1,000, 1,500, 2,000 and 2,500 $\mathrm{mg} \mathrm{AP} / \mathrm{kg}$ diets. Fishes fed without vitamin $\mathrm{C}$ supplementation presented bone deformation in head and jaws, and fin fragilities. Thus, $500 \mathrm{mg} \mathrm{AP} / \mathrm{kg}$ diet was enough to prevent deformation and the lack of vitamin $\mathrm{C}$ supplementation worsening the development of fingerlings.
\end{abstract}

Key words: scurvy, bone formation, siluriformes, ascorbic acid.

\section{INTRODUCTION}

The barred sorubim (Pseudoplatystoma fasciatum) and spotted pintado (Pseudoplatystoma corruscans), named surubins, are important fishes in the Brazilian aquaculture due to their characteristics as high growth and carcass yield (>50\%), absence of intramuscular spines, high commercial values and consumers (Smerman et al. 2002, Santos and Oba, 2009). But this species presents problems in larval and fingerlings culture, because the high mortality caused by cannibalism and stress susceptibility in the alimentary training to inert feed.

Correspondence to: Rodrigo Yudi Fujimoto

E-mail: ryfujim@hotmail.com
The vitamin $\mathrm{C}$ is a promoter of many biochemical and phisiological processes in animals and plants (Baraúna et al. 2009), act as cofactor of reactions to maintain the normal growth like prolin hydroxylation in the collagen synthesis, tryptophan hydroxylation to 5- hidroxitriptofan and in reaction of 3,4-dihidroxyphenylpiruvate to noraepinephrine (Baker 1967, Dabrowski 2001, Barros et al. 2002). The use of vitamin C in supplemented diet for fish also increases the growth and resistance to stress and anti-inflammatory effects in larvae and fingerling (Gaspasin et al. 1998, Chagas and Val. 2003, Martins et al. 2008). Many species of fish do not produce ascorbic acid 
due to the lack of enzyme gulono lactona oxidase, therefore the inclusion of this vitamin in diet is essential (O'keefe 2001).

The lack of this vitamin provokes the scurvy, as observed by Wilson and Poe (1973) and Li and Robinson (2001). Halver (1972) observed classical symptoms of scurvy in fish as scoliosis, low collagen formation and distortion of cartilage support. Gaspasin et al. (1998) observed low bone deformities index in larvae of "milkfish" (Chanos chanos) when they were fed with artemia and rotifers enriched with $1,750 \mathrm{mg}$ vitamin $\mathrm{C} / \mathrm{kg}$ dry weight of live foods (rotifer and artemia). The authors also reported higher growth and survival index in fish fed vitamin C.

The objective of this work was to evaluate the morphological deformities in bone and cartilage structure of spotted sorubim fingerlings fed with diets supplemented or not with ascorbyl polyphosphate as source of vitamin C.

\section{MATERIALS AND METHODS}

The experiment was conducted at the Laboratory of Aquatic Organisms Nutrition Aquaculture Center, UNESP - College of Agriculture and Veterinary Sciences, Jaboticabal Campus, Brazil.

The spotted sorubim fingerlings were obtained from the National Center for the Study of Tropical Fish - CEPTA (Pirassununga-SP), with one month old. Fish were first placed in tanks of $500 \mathrm{~L}$, for two weeks to acclimation to the artificial diet and to reduce the stress.

After this period, 126 juveniles were anesthetized ( $0.4 \mathrm{~g}$ benzocaine/15 $\mathrm{L}$ of water) to realize the biometry and then distributed in experimental aquaria in three weight classes: small, medium and large (average 1, 3 and $6 \mathrm{~g}$, respectively). This procedure was taken to prevent cannibalism by the high degree of heterogeneity of growth, found in this species. Monthly, the fingerlings of three replicates of each treatment were redistributed again in three weight classes. Each month was considered an experimental period $(\mathrm{P})$. At the end of each period, were made the biometry, measuring the weight, total length (TL), and the body was observed for possible deformities. Handling procedures were made in fish anesthetized with $0.4 \mathrm{~g}$ benzocaine $/ 15 \mathrm{~L}$.

Were used a total of 18 tanks with $100 \mathrm{~L}$ capacity, continuously supplied with water from an artesian well, with a total water change of about 20 times a day. The temperature was monitored daily, and dissolved oxygen weekly.

The water parameters were monitored throughout the experiment and the results remained within the standards for fish culture, mean of Oxygen dissolved 5.5. $\pm 1.35 \mathrm{mg} \mathrm{O}_{2} / \mathrm{L}$ and temperature of $29 \pm 1.5^{\circ} \mathrm{C}$.

A basal diet formulation was used to contain the optimal levels of nutrients for this experiment (Table I). This diet corresponded to the diet free of vitamin $\mathrm{C}$ treatment $(0 \mathrm{mg}$ of AP / $\mathrm{kg}$ diet $)$. For supplementation, the levels of ascorbyl polyphosphate (Stay C Rovimix, Roche) (500, 1,000, 1,500, 2,000 and 2,500 $\mathrm{mg} / \mathrm{kg}$ ) were added at the basal diet.

The source of vitamin $\mathrm{C}$ was incorporated into experimental diets, becoming a pre-mix and swirl up and mixed up with the rest of each match. By difficulties in acceptance of the dry diet, six semimoist diets were processed by grinding machine by adding $40 \%$ water for pelletizing.

After pelleting process of, the diets were packed and stored in a freezer at $-18^{\circ} \mathrm{C}$ conservation to minimize losses. Food was offered twice a day at 8:00 am and 19:00 pm. For fish conditioning, the water was briefly closed and the tanks aerated. Diets were fed ad libitum, and small quantities were taken to prevent losses, but until the fish did not seek more food.

During the three experimental periods, the occurrence of deformities such as spine deviation, retraction of the jaw, fin deformation (fragmentation and distortion) and convexity of the head was evaluated. Radiographs were taken from head and mouth to assess skeletal development in these regions. 
TABLE I

Basic composition of experimental diet.

\begin{tabular}{lc}
\hline INGREDIENTS & $\%$ \\
\hline Fish meal & 52.0 \\
Soybean meal & 21.0 \\
Wheat Bran & 8.00 \\
Corn & 13.5 \\
Soybean oil & 4.00 \\
Vitaminic and mineral premix * & 1.00 \\
\hline Calculated composition $* *$ & \\
Crude Protein $(\%)$ & 40.00 \\
fat $(\%)$ & 8.11 \\
Crude fiber $(\%)$ & 2.30 \\
Energy (kcal $/ \mathrm{kg}$ diet) & 4165 \\
Ca: P index & $2: 1$ \\
\hline
\end{tabular}

* Composition of vitaminic and mineral premix: Iron 15,000mg, Cupper $5,000 \mathrm{mg}$, Iodine $500 \mathrm{mg}$, Manganese 17,000 mg, Zinc 12,000 mg, 70 mg Selenium, vehicle 1,000g, 12,000 IU Vitamin A, Vitamin D3 1500 IU Vitamin E 50 mg, 4 mg Vitamin K, Vitamin B12 7 mg, 7 mg vitamin B2, acid $60 \mathrm{mg}$ Pantothenic Ac. Nicotinic $120 \mathrm{mg}, 600 \mathrm{mg}$ choline chloride, methionine $700 \mathrm{mg}, 500 \mathrm{mg}$ antioxidant, vehicle $1,000 \mathrm{~g}$.

** Calculated composition based on the results of testing of ingredients in accordance with AOAC (1975).

Statistical analyses and contrast analyses were realized to compare the occurrence of morphological deformities between fishes fed without supplementation and the group of fishes fed with supplementation of vitamin C.

\section{RESULTS AND DISCUSSION}

For this species, were not observed benefits of vitamin $\mathrm{C}$ supplementation in growth (Fujimoto and Carneiro 2001), but several authors cited improvements in immune parameters or prevention of deformities in other species, asserting that vitamin $\mathrm{C}$ is an essential nutrient in fish nutrition (Chagas and Val 2006, Pezzato et al. 2004). In the present study at the end of the experiment, the occurrence of morphological deformities in control animals ( $0 \mathrm{mg} \mathrm{AP} / \mathrm{kg}$ ) were observed compared to those fed 500 and 1,000 $\mathrm{mg}$ vit. $\mathrm{C} / \mathrm{kg}$ (Table II). The deformities in spotted sorubim fingerlings were found after the second month of experiment.
In contrast, Blom et al. (2000) did not observe any deformities in Pterophyllum scalare fingerling fed $0,30,120,360,720,1,440 \mathrm{mg}$ vitamin $\mathrm{C} / \mathrm{kg}$ diet, after fourteen weeks of experiment.

TABLE II

$F$ values, coefficient of variation and means of the deformities occurrences (Df) of pintados.

\begin{tabular}{|c|c|c|}
\hline & Statistics & $\operatorname{Df}(\%)$ \\
\hline & $\mathrm{F}$ for blocks & $1.55 \mathrm{~ns}$ \\
\hline & $\mathrm{F}$ for treatments & $11.71 * *$ \\
\hline & $F$ contrast: & \\
\hline Group with v & min $C X$ Group without vitamin $C$ & $54.29 * *$ \\
\hline & Linear effect & $3.89 \mathrm{~ns}$ \\
\hline & Quadratic effect & $0.12 \mathrm{~ns}$ \\
\hline & Cubic effect & $0.00 \mathrm{~ns}$ \\
\hline & tion coefficient $(\%)$ & 28.49 \\
\hline \multirow{6}{*}{ Means: } & $0 \mathrm{mg} \mathrm{AP} / \mathrm{kg}$ & 82.00 \\
\hline & $500 \mathrm{mg} \mathrm{AP} / \mathrm{kg}$ & 0.00 \\
\hline & $1,000 \mathrm{mg} \mathrm{AP} / \mathrm{kg}$ & 0.00 \\
\hline & $1,500 \mathrm{mg} \mathrm{AP} / \mathrm{kg}$ & 6.66 \\
\hline & $2,000 \mathrm{mg} \mathrm{AP} / \mathrm{kg}$ & 8.33 \\
\hline & $2,500 \mathrm{mg} \mathrm{AP} / \mathrm{kg}$ & 15.00 \\
\hline
\end{tabular}

Fish with high specific growth rates, tend to have more symptoms of scurvy due to rapid growth, indicating higher requirements of vitamin $\mathrm{C}$ for the whole development (Thompson et al. 1993), which may have been occurring to spoted sorubim fingerlings in this study. Other explanation for these differences in vitamin $\mathrm{C}$ requirement is related to different species and its level of development (Leonardo et al. 2001).

Deformities as head convexity (26.31\%), displacement of jaw line (31.57\%), distortion and fragility of fins $(31.57 \%)$, deviation of the spine $(10.52 \%)$ were also observed. Deformities of spine occur less frequently, as observed in trout (12.5\%) fed diets free of vitamin C (Madsen and Dalagaard 1999).

The occurrence of deformities increased as the vitamim $C$ supplementation $(2,000$ and 2,500 $\mathrm{mg}$ AP / kg diet), although not significantly, indicating that these levels could be causing symptoms of 
hyper-vitaminosis but not significantly harm to the body, for the fry fed these higher levels did not showed weakness of the fins.

Figure 2 shows the radiographs from spotted sorubim fingerling with deformities on the head and mouth, which occurred more frequently in the group fed the diet without vitamin C, demonstrating its importance bone formation.

Deformities as scoliosis and lordosis were reported in the studies of Lim and Lovell (1978), reaching $60.9 \%$ of the channel catfish fingerlings (Ictalurus punctatus) in vitamin $\mathrm{C}$ deficiency, that were similar to our findings. However in the present study a lower value $(10.52 \%)$ was related.

Mazik et al. (1987) founded higher deformity $(79 \%)$ than this study in vitamin-deficiency fish. Chavez de Martines (1990) reported deformities of jaw in Cichlasoma urophthalmus, observed at 45 days vitamin restriction. This abnormality was also observed in $31.57 \%$ of spotted sorubim fingerlings at 60 days of restriction.

One type of deformity was not reported in the literature, but frequently observed in unsuplement spotted sorubim $(26.31 \%)$ was the convexity of the head, clearly observed in Figures $1 \mathrm{~B}$ and $2 \mathrm{C}$. These deformities could provoke a decrease in the commercial value due to strange morphological aspect of fish.

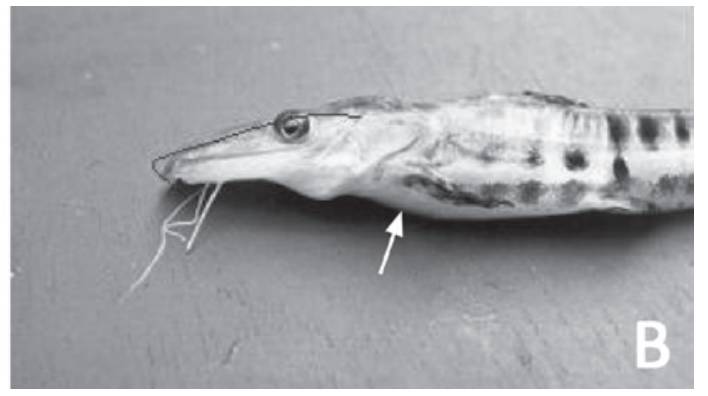

Figure 1 - A: fish head without convexity; B: head deformity in pintados fingerlings not supplemented with vitamin. Arrows and lines in indicate deformities: lines, convex head, arrow indicates weakness and distortion of the fins. Scale bar $=1 \mathrm{~cm}$.

The vitamin $\mathrm{C}$ is essential for collagen fibers formation that participates in the formation of the pro-collagen structure. This disability and injuries prejudice the heal and bone formation as supported by Wang et al. (2003), Moraes et al. (2003), Junqueira and Carneiro (1999). Thus, a deficiency in the formation of this tissue may be responsible for deformities and fragility of the fins, since the tissue is important for the body, performing duties of defense, transportation, storage, and regeneration (Gartner and Hiatt 1993).

\section{RESUMO}

A vitamina $C$ é essencial para dietas de peixe porque muitas espécies não conseguem sintetizá-la. Esta vitamina é necessária par a formação de cartilagem e matriz óssea. Além disso, age como antioxidante e melhora as resposta do sistema imunológico. O presente trabalho investigou os efeitos da suplementação de vitamina $\mathrm{C}$ em dietas para alevinos de pintado (Pseudoplatystoma corruscans) pela incidência de deformidades na estrutura óssea e cartilaginosa. $\mathrm{O}$ ascorbil polifosfato (AP) foi utilizado como fonte de vitamina $\mathrm{C}$ em dietas para alevinos de pintado durante o período de três meses. Seis dietas foram formuladas: uma dieta controle $(0 \mathrm{mg}$ de vitamina $\mathrm{C} / \mathrm{kg}$ ) e cinco dietas 500, 1.000, 1.500, 2.000 e $2.500 \mathrm{mg}$ de AP / kg. Os peixes alimentados sem suplementação de vitamina $\mathrm{C}$ apresentaram deformidades óssea na cabeça e mandíbula e fragilidade de nadadeiras. Assim, a dieta de $500 \mathrm{mg}$ de $\mathrm{AP} / \mathrm{kg}$ foi suficiente para prevenir a ocorrência de deformidades, e a ausência desta vitamina prejudica o desenvolvimento ósseo de juvenis de pintados.

Palavras-chave: escorbuto, deformação óssea, siluriformes, acido ascórbico. 

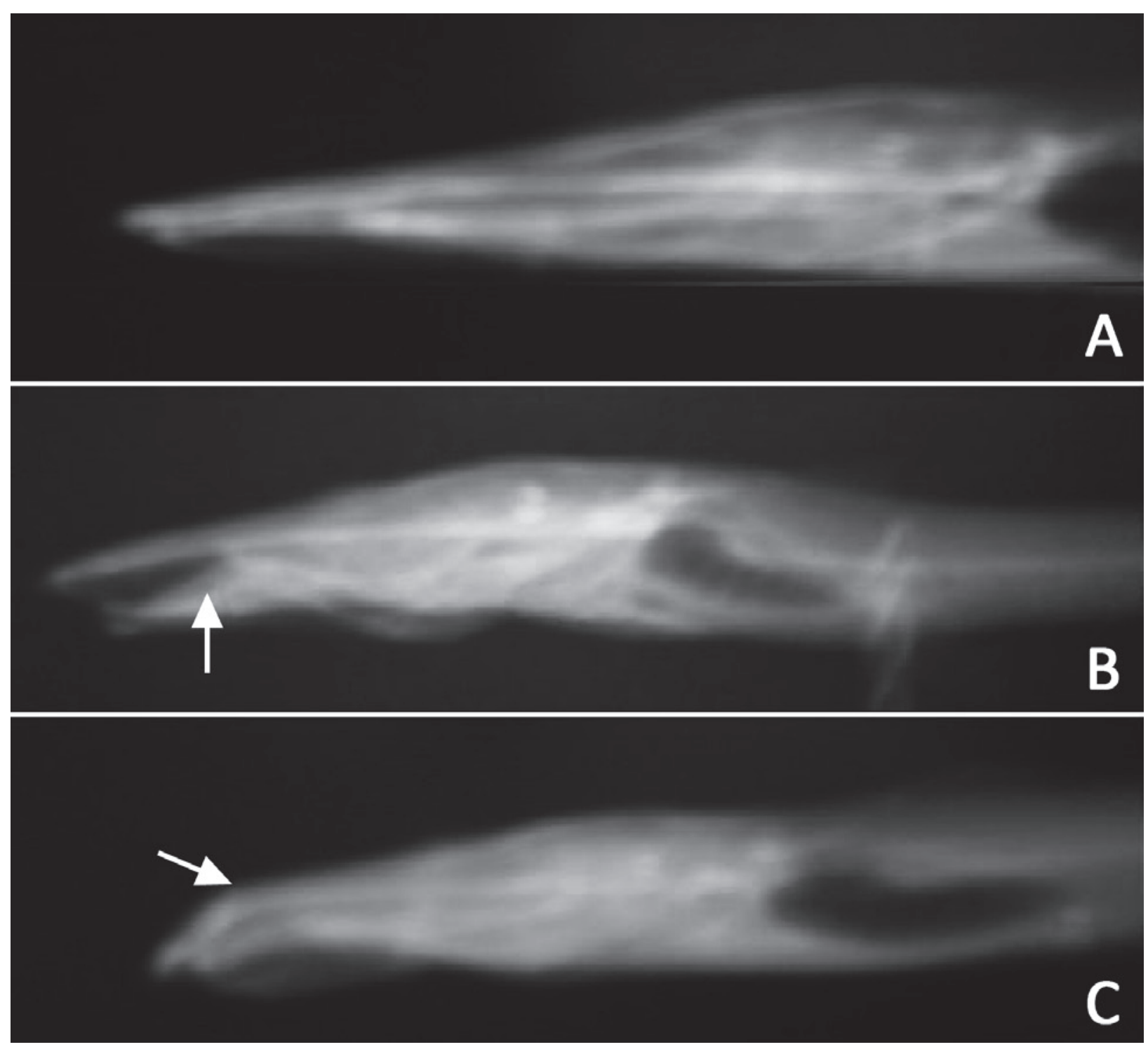

Fig 2 - Plate of X ray pintado fingerlings showing: A: normal fish; B: deformity of jaw line (arrow) and C: head convexity (arrow). scale bar $=0.5 \mathrm{~cm}$.

\section{REFERENCES}

AOAC - Official Methods of Association of Official Agricultural Chemists. 1975. $3^{\text {rd }}$ ed., Washinghton AOAC, 975 p.

BAKER EM. 1967. Vitamin C requirements in stress. The Am J Clin Nutr 20: 583-590.

BARAúna LCRI, COSTA DSP, CARVALHO JV, LiRA AD, AlmeIDA TR, GARCEZ Neto AF, LABORDAL SS, Albinati RCB, Oliveira EMD AND Silva MCA. 2009. Utilização de duas diferentes megadoses de vitamina $C$ na ração de alevinos de tilapia do Nilo (oreochromis niloticus) submetidos a infecção experimental por Edwardsiella tarda. Arq do Inst de Biol 76: 561-567.
Barros MM, Pezzato L and KleEmann GK. 2002. Níveis de vitamina $\mathrm{C}$ e ferro para tilápia do Nilo (Oreochromis niloticus). Rev Bras Zoot 31: 2149-2159.

Blom JH, DABRowski K AND Ebeling J. 2000. Vitamin C requirements of the Angelfish Pterophylum scalare. J World Aquac Soc 31: 115-118.

Chagas EC And VAL AL. 2003. Efeito da vitamina C no ganho de peso e em parâmetros hematológicos de tambaqui. Pesqui Agro Bras 3: 397-402.

Chagas EC AND Val AL. 2006. Ascorbic acid reduces the effects of hypoxia on the Amazon fish tambaqui. J Fish Biol 69: 608-612.

Chavez DE MARTINes MC. 1990. Vitamin C requeriment of the mexican native cichlid Cichlasoma urophthalmus (Gunther). Aquaculture 86: 409-416. 
DABROWSKI K. 2001. Ascorbic Acid in Aquatic Organisms Status and perspectives. CRC Press, Boca Raton, FL, USA.

FUJIMOTO RY AND CARNEIRO DJ. 2001. Adição de ascorbil polifosfato, como fonte de vitamina $\mathrm{C}$, em dietas para alevinos de pintado, Pseudoplatystoma corruscans (Agassiz, 1829). Acta Sci Maringá 23: 855-861.

GARTNER LP AND HiATT JL. 1993. Atlas de histologia. Rio de Janeiro, editora Guanabara Koogan SA, 322 p.

GASPASIN RSJ, Bombeo R, LAVENS P, SORgeloos P AND NELIS H. 1998. Enrichment of live food with essential fatty acids and vitamin C: effects on milkfish (Chanos chanos) larval performance. Aquaculture 162: 269-286.

HALVER JE. 1972. The role of ascorbic acid in fish disease and tissue repair. Bull Jap Soc Fish Oceanogr 38: 79-92.

JunQUEIRA LC AND CARNEIRO J. 1999. Tecido ósseo. In: Histologia básica. $9^{\mathrm{a}}$ ed., Rio de Janeiro: GuanabaraKoogan, cap. 8, p. 111-128.

LEONARdo JMLO, VARgas L, Ribeiro RP, Moreira HLM, NATALI MRM, VOSKI T AND CAVICHIOLO F. 2001. Histologia das brânquias de larvas da tilápia do Nilo, Oreochromis niloticus (L.), de origem tailandesa, submetidas a diferentes níveis de vitamina C. Acta Sci 23: 863-870.

LI MH AND ROBINSON EH. 2001. Dietary ascorbic acid requirement for growth and health in fish. In: LIM C AND WEBSTER CD. Nutrition and fish health. Haworth Press, New York, p. 163-175.

LIM C AND LOvell RT. 1978. Pathology of the vitamin C deficiency syndrome in Channel Catfish (Ictalurus punctatus). J Nutr 108: 1137-1146.

MADSEN L AND DALAGAARD I. 1999. Vertebral common deformities in farmed rainbow trout (O. mikiss). Aquaculture 171: 41-48.

MARTINS ML, MiYAZAKI DMY, MORAES FR DE, GHIRALDELLI L, ADAMANTE DE B AND MOURIÑO JLP. 2008. Ração suplementada com vitaminas $\mathrm{C}$ e E influência a resposta inflamatória aguda em tilápia do Nilo. Cienc Rural: 38: 213-218.

MAZIK PM, BRANDT TM AND TOMASSO JR. 1987. Effects of dietary vitamin $\mathrm{C}$ on growth, caudal fin development, and tolerance of aquaculture-related stressors in Channel catfish. Prog Fish-Cult 49: 6-13.
Moraes JRE, Freitas JB DE, Bozzo FR, MORAEs FR DE AND MARTINS ML. 2003. A suplementação alimentar com vitamina $\mathrm{C}$ acelera a evolução do processo cicatrial em Piaractus mesopotamicus (HOLMBERG, 1887). Bol Inst Pesca 29: 57-67.

O'KeEFE T. 2001. Ascorbic acid and stable ascorbate esters as sources of vitamin $\mathrm{C}$ in aquaculture feeds. Singapore: American Soybean Association (ASA) - United Soybean Board. 8 p. (ASA Technical Bulletin, AQ48-2001). Disponível em: <http://www.asasea.com/aq48_2001.html>. Acesso em: 12 dez. 2005.

Pezzato LE, Barros MM, Fracalossi DM AND Cyrino JEP. 2004. Nutrição de peixes. In: CYRINO JEP, URBINATTI EC, FRACALOSSI DM and CASTAGNOLLI N (Eds), Tópicos especiais em piscicultura de água doce tropical intensiva. São Paulo: TecArt, p. 75-169.

SANTOS LBS DOS AND OBA ET. 2009. Dieta: ferramenta importante para o manejo dos peixes no cultivo. In: TAVARES - DIAS M (Ed), Manejo e sanidade de peixes em cultivo. Macapá: Embrapá Amapá, p. 89-105.

Smerman W, Castro JGO, Toledo JJ DE, Rosa CAS da AND GODOI DS DE. 2002. Larvicultura de pintado (Pseudoplatystoma sp.) em alta floresta - Mato Grosso. Rev Biol Ciênc Terra 2: 1-7.

Thompson I, White A, Fletcher TC, Houlihan DF AND SECOMBES CJ. 1993. The effect of stress on the imune response of Atlantic Salmon (Salmo salar L.) fed diets containing differents amounts of vitamin C. Aquaculture 114: $1-18$.

WANG X, KIM K, BAI SC, HUH M AND CHO B. 2003. Effects of the different levels of dietary vitamin $\mathrm{C}$ on growth and tissue ascorbic acid changes in parrot fish (Oplegnathus fasciatus). Aquaculture 215: 203-211.

WILSON RP AND POE WE. 1973. Impaired collagen formation in the scorbutic catfish. J Nutr 103: 1359-1364. 